THURSDAY, DECEMBER 9, I869

\section{SCIENCE AND THE PUBLIC HEALTH}

$\triangle M O N G$ the wide range of subjects included in the programme of NATURE, one of the most important to mankind in general is certainly "the public health." We propose in the following article to lay before our readers an account of the way in which the attention of different nations, at various times, has been directed to this matter, until at last it is beginning to be recognised as a necessary study for all.

It would seem at first sight hardly necessary to spend words on defining the aims of a science, of which the name "Health" is so expressive, but the various writers on the subject have not thought so, and the old formula, "the art of preserving the health," has been often changed.

Londe, apparently from a dietetic point of view, says, "Hygiene is the science which has for its object the direction of the organs in the exercise of their functions," a definition which strangely limits the subject, and even excludes the most important and interesting part of it.

Oesterlen, desirous of bringing into view the two great divisions of hygiene, calls it "that part of our knowledge which has to do with the preservation and furthering of the health of individuals on the one hand, and of the community at large on the other."

Michel Lévy says that it is "the clinical study of healthy man," by which definition he wishes to individualise the more general one ; but even here we do not find what we want: indeed we prefer the original definition to all these alterations of it. Dr. Parkes thinks so too, for he says, "Hygiene is the art of preserving health, that is, of obtaining the most perfect action of body and mind during as long a period as is consistent with the laws of life ; in other words, it aims at rendering growth more perfect, decay less rapid, life more vigorous, death more remote."

And now we come to the extension which Bouchardat has given to the ordinary detinition, "Hygiene is the art of preserving the health." But how can we preserve health? Plainly by doing our best to keep away disease. And how can we do this? By checking the causes of disease. To this end we must know these causes,-and here we have the grand object of hygiene; it is the science which studies the causes of disease, and points out the means of avoiding them.

The knowledge of causes is the great aim of all science properly so called, and no study ought to be honoured with that name which has not this end in view.

"Prevention is better than cure" is an old proverb, and, what is more, a very true one, and it is prevention that the hygienist studies-prevention of disease of whatsoever kind by the removal of its causes. The means by which diseases are prevented are often those which answer best for their cure; and here we perceive the link which joins hygiene with medicine, and which constitutes what we may call the therapeutical side of our science.

Thus we see that hygiene takes into consideration, incidentally as it were, and in connection with medicine, the treatment of many forms of disease by methods other than the employment of pharmaceutical preparationsthese methods are what Fonssagrives calls "the Hygienic Modificators," and are such as exercise, baths, change of employment, sea royages, residence in a different climate and above all regimen.

As the methods for the preservation of health are of the first importance to all human beings, we may expect to find provisions to this end among the writings of the ancients, especially in the codes of the lawgivers : and such is the case; take for example the writings of Moses; they are replete with most excellent hygienic regulations, which his followers were obliged to observe under pain of severe penalties.

Look at the institution of circumcision, the provisions for the separation of the lepers from the healthy penple, the command not to eat swine's flesh, the prohibition of the marringe of near relations. Besides these and many other important generalities, we find the great Hebrew legislator descending to the inmost details of family life-giving a regimen admirable in its adaptation to the climate of the countries for which it was intended; directing the burial of excrementa and refuse matter of all sorts in the earth; fixing the laws of marriage, of concubinage, of servitude, and of all social relations.

It is to the strict observation of these sanitary regula tions that one of the best-known writers on hygiene of the present day, M. Michel Lévy, does not hesitate to ascribe the singular immunity of the Jewish race in the midst of fearfully fatal epidemics; which immunity was so marked in the middle ages, that it brought upon them "accusations the most absurd, persecutions the most atrocious."

We turn now for a moment to China, and find a papple in many respects in a very high state of civilisation, a people who had used the mariner's compass ages before it was known in Europe; but a people who, from want of communication with other nations, have made no advance at all, perhaps, for thousands of years, who have gone on increasing in numbers at such a rate that they now form onethird of the population of the whole world, so that their country is crowcled to an extent hardly conceivable. Surely we can learn something from them which will be of service to us in the management of our overgrown towns! Yes; in one thing at least they are our masters - they waste nothing; what they take from the earth they give back directly to the earth ; every atom of their sewage matter is employed as manure ; and how otherwise wonld it have been possible for so immense a population, without anv external resources, to live on such a comparatively limited portion of the earth's surface, and to keep it fertile for so many centuries?

One of the best instances of the power of cultivation in improving the condition of a country is to be found in Lower Egypt, formerly the centre of civilisation of the world, now in a most abject condition : the inundations of the Nile, while the country was peopled with intelligent races, were the great source of its fertility, but are now the cause of the insalubrious marshes that generate the Plague, and make that country one of the most unhealthy spots on the face of the globe.

To come nearer to our own country, let us see what were the hygienic conditions of ancient Greece and Rome. Had the practical application of the principles of public health anything to do with the high state of civilisation to which those countres rose-a state which has, in some respects at any rate, never since been equalled? Had it 
anything to do with the success which attended the Roman armies, and led to the formation of that enormous Roman empire? Let the facts speak for themselves. What strikes one more in reading the classical authors of those countries than the continual mention of gymnasia and of baths? We find that a certain portion of time was set apart daily for bodily exercise, and this a full development of the body was produced, and the greatest resistance given to those two great enemies of mankind, disease and death. It is true that all this training was part of a grand military system, that the youths were thus encouraged to compete for the prizes in the Olympic games and in the Roman gymnasia tixat they might become good soldiers; but did this prevent the cultivation of mental acquirements? Again let the facts give the decision. Do you wish to see fine buildings, buildings so well constructed that they have lasted comparatively untouched by decay for centuries? Do you wish to study beautiful sculptures, statues anatomically perfect to the minutest details, and of unsurpassed artistic elegance? You go to Athens! You go to Rome! Do not fancy that we contend for bodily exercise as against mental studies: we merely maintain that a sufficient daily corporal exercise is absolutely necessary for the proper performance of the functions, both of mind and body.

But we have not yet done with Rome. We have mentioned the baths of that city; but how were they supplied with water? Ah! here we have need to hide our faces for shame. Surely we, with all the immense advantages of scientific engineering, manage to supply our cities with water as well as the people of two thousand years ago; at any rate, with all our steam engines and manufactories, we require at least as much as they did. When we turn to the pages of Frontinus, what do we find? That at the time at which he wrote, about A.D. 92, there were actually nine large aqueducts by which water was brought into Rome, beside some smaller channels; these aqueducts were in some cases entirely covered over throughout their whole length, and were driven underground or supported by high arches, as occasion required. Several of them, as the Anio Vetus, the Claudian, and the Anio Novus, were from 42 to 49 miles in length, while the total length of the Marcian was actually 54 miles. The water was brought by the two Anios from the river Anio, by the others from various springs and lakes around Rome; the two newest ones, the Claudian and the Anio Novus, were made because "seven aqueducts seemed scarcely sufficient for private purposes and public amusements."

The supply appears to have been equivalent to more than 332 millions of gallons per day, or (since the population was certainly not more than a million) at least 332 gallons per head per day-say, six times the amount that we have now in London.

But beside the aqueducts, there was a capital system of sewers at Rome, consisting of the "Cloaca Maxima" and a series of smaller channels flowing into it. The above remarks give an idea of the admirable manner in which the means for the conservation of the public health were made a subject of State legislation in ancient Rome, and of the determined way in which all obstacles were vanquished, in order that the city might be made as healthy as possible.

Not only have we the example of the ancients in these matters, but we have hygiene reduced to a system by Hippocrates, and associated, as it should always be, with medicine. In reading his Aphorisms, one is struck by the excellent dietetic regulations which he gives, for the observance of gymnasts, and for the guidance of plysicians in treating acute and chronic diseases. His third section, which treats of the influence of the seasons of the year, and of the various ages of man in the production of diseases, is also very remarkable.

The very names of the works of Hippocrates show how great a hygienist he was. "About Food," "About the Use of Liquids," "About the Diet of Healthy People," and especially his treatises on "Air, Water, and Localities," and on "Epidemics," are works which well entitle their author to be considered the father of experimental hygiene.

After Hippocrates comes Celsus, during the Ist century of our era, who devotes the first chapter of his first book "De Re Medica" to the exposition of rules concerning diet, and recommends the avoidance of too great regularity by healthy persons.

But we must not pass over the works of Galen, which were so numerous as to form a complete treatise of medicine, and which exercised so enormous an influence over the medical practice of the whole world during many centuries. Galen flourished during the latter part of the and century after Christ, and was for some time plysician to the gymnasia at Rome. He revived the doctrines of Hippocrates, especially the celebrated one of the four humours (blood, bile, phlegm, and atrabile), and considered that the different temperaments were produced by mixtures in various proportions of these humours with the four elements-earth, air, fire, and water, and with the four physical qualities-heat, cold, moisture, and dryness.

The Sicilian School sprang up in the I Ith century, and was the offspring of the ancient Greek and Arabian medical schools. Its practice is handed down to us in a quaint Latin poem, in which a great deal of truth is mixed up with a great deal of trash, and in which we find bad therapeutics based upon faulty pathology. It is from this school that the doctrines of Hippocrates and Galen, together with the fancies of later times, were spread abroad over Europe. Thus we find that the experimental methods of the fathers of medicine were confused with a host of traditions derived from the Arabian alchemists; so that the rational methods of treatment, adopted by Hippocrates and his more immediate successors, were neglected; and diseases were treated instead by a host of supposed infallible remedies, of which the action was not at all investigated. And what do we find as the result of this change of practice? That epidemics raged with the most fearful intensity all over Europe, epidemics which were only known accidentally before, and which, finding favourable conditions for their spread in the utter neglect of hygienic observances, came from their natural seats in hot eastern countries, and committed unheard-of ravages in Europe. Look at the Plague, that fearful epidemic of the eastern part of the Mediterranean! It is true that we have accounts of terrible visitations of it in Greece, and particularly of one which depopulated Athens in the second year of the Peloponnesian war, when the disease was introduced into that city (then fearfully overcrowded) by a ship from 
Egypt, that entered the Piræus: at various times also, and particularly in the year of the city 389 (before the building of the aqueducts), the Roman capital was visited with the same calamity: but this is nothing to the fearful visitations with which all Europe was afflicted during the 14th, 15th, 16th, and I 7 th centuries.

The last appearance of the Plague in Europe was in 1719, when it was introduced into Marseilles by a ship that had been refused admittance into the port of Cagliari in Sardinia. Even then its course might probably have been stopped, had its malignant nature been recognised soon enough; but this was not the case, and more than 90,000 persons were killed by it. Here we have a clear proof of the value of preventive measures. Sardinia was saved because the king refused the admission of the ship into the port of Cagliari; Marseilles was ravaged because a like precaution was not taken.

In England we are accustomed to manage affairs in a less official manner than they are managed abroad, and the result is that improvements, although more difficult of introduction, are often more surely brought about with us than with our neighbours. It is certainly not because we are less hygienic in our habits than other nations, that we have so few books on hygiene, or that our Medical Schools have not looked upon it as a sister science with Medicine; but because it seemed to take no special line, and because it seemed to be so much everybody's business: now, however, since the formation of the General Board of Health and the Registrar-General's office, such a mass of information with regard to the statistics and to the causes of disease has been obtained, that it seems necessary to make a special study of this science, and no longer to allow it to be taught accidentally as an appendage to Pathology or Therapeutics.

W. H. CORFIELD

\section{SCIENCE EDUCATION IN GERMANY}

\section{I.-THE GERMAN UNIVERSITY SYSTEM}

THE most striking point of difference between the condition of science teaching in Germany and in England lies in the great facilities and encouragements which, in the former country, are given to the study of science in its highest development. In primary education, we are in England probably doing as much or more in the way of encouraging the teaching of elementary science as is being done in Germany, or elsewhere. It is our richly endowed Universities which have as yet failed to play the important part in this essential feature of modern education which, from their position and means, we have a right to expect them to do, whilst other less wealthy Colleges and educational establishments, quite as capable of giving the highest scientific instruction, have to battle with almost overwhelming difficulties, Government, on the other hand, true to its supposed function of simply assisting those who cannot help themselves, only gives pecuniary aid towards the science instruction of the working classes; and, with a singular want of foresight, provides no systematic means of training the teachers, * who are left to pick up their education as best they may.

* The few Queen's prizes and other exhibitions for instruction in the Royal School of Mines cannot in any respect be considered as a system of science edication for teachers.
The university system of Germany is now so different in character from that of England, that it is difficuit to believe that these institutions, of the same age and standing, were founded on the same type, and perhaps equally so to explain how they came to be so essentially different. The cause of this difference appears, however, to me to lie less in the necessarily varying nature of national character and requirements, than in the simple fact that in Oxford and Cambridge the system of colleges founded originally as benefactions to religious societies by private donors, and still retaining a party and religious character, has swamped (or nearly so) the university; and that the college tuition interferes with, and is indeed often absolutely opposed to, that of the proper educating body which it was intended only to supplement. In Germany the college system does not exist, and the university has always remained supreme in its locality; it knows of no interference, religious or otherwise, in its own sphere; its system of education is regulated according to one prixciple, and one spirit of emulation pervades the whole staff of teachers.

It is singular to notice that the German universities, which are all of them Government institutions, every professor being a civil servant of the Crown, taking the oaths and receiving salary and pension, do not suffer from what we are apt to consider the deadening influence of Government service. On the contrary, this system now holds, and has always contained, the highest and best intellectual life of the nation, replete with energy both as regards teaching power and original research. This may be explained by the fact that although the universities arc State institutions, yet they are practically free as regards their internal government. Each Professor teaches as he thinks best, and Ministerial interference with the regulations of the Senate is of the rarest occurrence. In another point of view, it is well to compare the Government universities of what we Englishmen are even yet too apt to consider as the despotic and illiberal German powers with our free (!) universities. In Germany all, from prince to peasant, who choose, can and do come to the university, provided they bring certificates of having passed the exit examination of their gymnasium, as a proof of due qualification to benefit from the university instruction. Thus, the small government of Baden supports two universities, to the benefits of which persons of all classes, of all religious denominations, and natives of all countries are permitted to enter, without limitation of number, without religious test of any kind, and for the payment of ridiculously low fees. Can we say that our universities are as free? or that we in England possess any other institutions which fulfil for us the duties of these High Schools for the German people?

The university system of Germany has most certainly succeeded in stimulating intellectual activity, and fostering a spirit of original inquiry amongst the teachers, and thus creating a true profession of learned men. On the other hand, it offers sufficient inducement to aspiring students to devote themselves to special pursuits, and raise their aims to something higher than mere "Brodstudien," by opening out to them a path, often arduous and rugged, by which a man of ability may rise, from privat-docent and extraordinary professor, to the highest position of university eminence. This free infusion of 